\title{
TRANSFORMATIONS OF FAMILY STRUCTURES: PERCEPTION OF NEW FAMILY MODELS IN THE REPUBLIC OF NORTH MACEDONIA
}

\begin{abstract}
Historical and demographic processes have significantly influenced the transformation from traditional to modern family, changing its structure, functions, partnerships, as well as parenting and child rearing, perceptions of marriage, divorce, birth-rates, etc. After the Industrial revolution, the nuclear family became the dominant model of family in Europe and it is still prevailing in the Macedonian contemporary society.

Social changes such as globalization, individualization, secularization, and the dynamics of modern living have led to new family forms that reflect modern societies. This paper will present a brief analysis of family structures, the transformation from traditional to modern family and it will discuss new family models. Particularly, it will focus on cohabitation, multi-ethnic families and same-sex relationships in the Republic of North Macedonia by presenting the results of a qualitative research on perception of new family models in North Macedonia conducted during 2019.
\end{abstract}

Keywords: FAMILY MODELS, COHABITATION, MULTI-ETHNIC FAMILIES, SAME-SEX RELATIONSHIPS, NORTH MACEDONIA

\section{Introduction}

Social, demographic and historical processes have continuously influenced family, its structure, functions, partnerships and parents-children relations. There is a general perception that the traditional patriarchal and extended family, characteristic of pre-industrial societies, was static and unaltered, however, there were different family structures in the past as well, although not widely represented. Undoubtedly, after the Industrial revolution, the nuclear family composed by parents and their children became the dominant family model in Europe and it is still prevailing in the Macedonian contemporary society.

Social changes after the 1950s, such as globalization, secularization, the flourishing of feminist ideas, women's emancipation, individualization, and other social processes, further changed family structures, marriage, divorce, and birth-rates. Today, the definition of the contemporary family needs to be broad enough to cover all family models, their dynamics and functions, and 
that is the main reason we are no longer discussing about a single definition of family, but various family models.

This paper will present a brief analysis of the transformation of family from traditional to modern, with a focus on its structural changes in Europe and the Balkans. Additionally, we will review new family models in the contemporary Macedonian society focusing on cohabitation, multi-ethnic families and same-sex relationships. Finally, the paper will present the results of a qualitative research on the perception of new family models in North Macedonia which was conducted during 2019.

\section{From traditional to modern family}

The main structural changes of the European family were observed after the Industrial revolution, which began in England in the mid-18 $18^{\text {th }}$ century, however, arrived much later on the Balkan Peninsula and in North Macedonia. The transformation from traditional to modern family concerns primarily its structure from extended to nuclear form, that is, the separation of children from their parents after marriage, caused predominantly by the processes of industrialization and urbanization, as well as the frequent population migration from village to city. Nevertheless, it must be noted that the extended family persisted in the Balkans for a much longer period and this family structure (parents and children and their families, married and unmarried siblings, that is, relatives along horizontal and vertical lines) were still present during the $20^{\text {th }}$ century.

Sociologists do not always agree on the reasons for the transition from traditional to modern family. According to Frederick Le Play's evolutionary concept, the nuclear family (parents and their children) in Europe is a result of the transformation of the extended family characteristic for the traditional preindustrial society. The sociologist claims that industrialization, as well as the processes of geographical mobility and urbanization, have relocated young people to the cities in search of work, creating at the same time an inevitably separate family unit. Peter Laslett, on the other hand, in his research from the 1970s claims that the nuclear family has been present in England since the $16^{\text {th }}$ century, as a residue of the extended family that became nuclear due to the early death of parents, given the shorter lifespan of the past centuries (Мицковиќ, 2008, 27-37).

Peter Laslett's classification (Laslett, Wall, 1972) distinguishes six types of households, including several family types:

1. Solitaries. Single households inhabited by a widower/widow or single people without a marital status.

2. No family. People living together who according to Laslett do not constitute a family: (a) unmarried siblings living without a co-resident parent; (b) other types of relatives living together (cousins, aunt and granddaughter, grandmother and grandson, etc.); (c) unrelated co-resident persons (for example roommates). 
3. Simple family. Nuclear families: couples and their children: (a) married couple without children; (b) married couple with children (c) widower with children and (d) widow with children.

4. Extended family: (a) extended upwards: includes a widowed parent of the father or mother in the nuclear family or not-married siblings of the parents; (b) extended downwards: includes unmarried grandchildren; (c) extended laterally: includes unmarried siblings of the father or mother in the nuclear family or the children of siblings and (d) a combination of the previous three types of families.

5. Multiple families or households containing more than one couple who are closely related in some way: (a) second unit upwards, ex. Married couple and the wife's parents; (b) second unit downwards, ex. couple and a married child with spouse; (c) unit on one level, ex. widowed parent plus two or more of their married children; (d) frereches - a French term denoting co-resident siblings. According to Laslett, it is a household with more than one married sibling, but no co-resident parent. (e) Other multiple families.

6. Indeterminate household.

In North Macedonia and in the Balkans in general, the transition from traditional to modern society came much later than in Western Europe. Balkan families had many forms of households, among which the most notable were the large and complex households inhabited by multi-generational families, (socalled zadrugas) that were present in the Balkan Peninsula until the $20^{\text {th }}$ century. This type of extended families were most prevalent in Central and Northern Macedonia, Bosnia and Herzegovina and North-Western Bulgaria, and were productive households engaged in stockbreeding and farming. Although zadrugas have a more complex structure and kinship system, they differ in the labour organization and inheritance system from typical European extended families, however are comparable to the extended and multiple families according to Laslett's household classification (Wall, Harevan, Ehmer, Cerman, 2001, 242- 256).

In addition to structural transformations, modern families have undergone significant alterations in family relations and functions, partnerships, and parent-child relations, the most significant of which are: the rejection of the inheritance system based on primogeniture; enhanced emotional relations between parents and children; improved parental care for the health, nutrition, education and future of their children; decrease in the birthrate (scientific and medical findings had reduced the high mortality rate from the past); the emergence of the cult of the woman as mother and wife (Мицковиќ, 2008).

Finally, the most significant changes in family relations and structures follow the revolutions of the 1960s (hippie movement) and the 1970s (feminism). Up to women's active participation in the labour market, she remained at home in the role of housewife, wife and caregiver. In Europe during the First and Second World Wars, women, in absence of husbands and fathers (who 
became soldiers), were employed in various sectors and became the economic providers of the household. In the interwar period, they returned to their homes, and only after World War Two and the diffusion of feminist ideas, they enhanced economic emancipation. Furthermore, with the introduction of contraception, women began to control their reproductive function. These events additionally altered the structure of the family, marriage, divorce, partnerships, and birth-rates (Nazio, 2008). As a consequence, marriages were no longer an institution that guarantees financial stability for women and children and a union to regulate sexual relations.

Undoubtedly, historical and demographic processes have greatly influenced the transformation from traditional to modern family, significantly changing its structure, functions, partnerships, as well as parenting styles, perception of marriage, divorce, birth-rates, etc. The processes we have analysed in this part of the paper, as well as additional social changes and the dynamics of modern living have led to new family models that reflect modern societies and will be elaborated in the next part of the study.

\section{Families in plural form}

The emergence of social processes such as globalization, secularization, urbanization, industrialization and the rapid development of modern technologies during the late $20^{\text {th }}$ and early $21^{\text {st }}$ centuries have contributed to the transformation of family structures and functions in the Republic of North Macedonia. Today, as in the past, there is no single definition of family, instead we are defining several family models. Although the nuclear family remains the dominant family model in North Macedonia, over the past decades we have witnessed the decreased number of traditional family forms and partnerships and presence of new family models, including:

- cohabiting families (a non-married couple living together with or without children);

- single parent families (families consisting of one parent and one or more children);

- reconstructed families (a married couple with at least one child from a previous relationship);

- same-sex families (families whose partners are of the same sex);

- migrant families (families who have left the country of origin);

- adoptive families (families with at least one adopted child);

- foster families (families caring for a child without parental care).

- multi-ethnic/multiracial families (families whose partners are from different ethnicity, race or religion, commonly known as mixed marriages).

Our analysis will focus on three family models: (1) cohabiting families, a family model that is increasingly represented in North Macedonia; (2) homosexual families, the least visible family model in the public space of modern 
Macedonian society, and (3) multi-ethnic families, which are not fully accepted even though North Macedonia is a multicultural and multi-confessional state.

A cohabiting family is defined as a union in which two persons live together as a couple without getting married (Nazio, 2008, 3). According to the Family Law in North Macedonia it is further specified that a cohabiting family represents a union of a man and a woman that lasted at least one year, during which they can enjoy the same rights as the partners of a marital communities, such as the right to protection from family violence, property rights and the right to mutual support (Family Law, 2014). The increasing number of cohabiting families is a consequence of several processes including: social acceptance of premarital sexual relationships, diminished trust in marriage as an institution, postponement of parenthood, increased number of divorces, change in partners' relations and gender roles, and the emancipation of women (Karraker, 2008). These changes and trends are followed by North Macedonia, in which, according to the last official census of 2002, there were 6.027 cohabiting families (State Statistical Office of the Republic of Macedonia, 2004), a number that we believe is much higher today. At the same time, the data show a steady increase of children born in extramarital relationships who in the past decade represent about $11 \%$ of the total number of children born in North Macedonia, and in 2018 reached $12.1 \%$ or 2,587 out of a total of 21.333 born children (State Statistical Office of the Republic of North Macedonia, 2019). Today, cohabiting families are popular with the Macedonian younger population, who do not completely reject marriage but prefer to live with their partner for some time in a permanent extramarital union or a temporary "premarital union" (Авировиќ, 2017).

Multi-ethnic/multiracial families are families whose parents are from different ethnic, religious or racial group. Although North Macedonia is a multi-ethnic and multi-confessional state, however, mixed marriages are not yet fully socially accepted, especially when it comes to partners of different religions. For both homosexual partnerships and multi-ethnic families, we do not have enough statistical data to analyse them and almost all researches on this topic are of a qualitative character. Previous studies show that the degree of religiosity of people affects the acceptance of these family models, especially when it comes to marriages between partners who are of different religion (Попоска, Стојановски, 2016).

Homosexual couples that is families whose partners are of the same sex cannot legally marry in the Republic of North Macedonia. At the same time, the members of this family models are subject to discrimination and are not fully accepted in our contemporary society, thus the absence of official data on their number. The first country in Europe to legalize same-sex marriage was the Netherlands in 2001, followed by 28 other countries in the world with different rights to adopt children (Oinonen, 2008). In order to increase the rights and visibility of the members of the LGBT community, in 2019 North Macedonia held the first pride parade named "Skopje Pride", which received strong support from activists in the region, foreign ambassadors and politicians, but 
due to the likelihood of incidents, police security was provided, and at the same time a parallel march to preserve traditional values was held. Previous research has shown that homophobia is present in more religious and traditional societies and that older people are more prone to homophobia than the youth (Mitchell, Fries, 2016), the latter being one of our hypothesis in the research presented in the next section of this paper.

\section{Research on the perception of new family models in contemporary Macedo- nian society}

Official statistics on different family models in contemporary Macedonian society are insufficient or unavailable for several reasons. Primarily, the absence of a census in the country since 2002, which includes the number of marital and cohabiting families. In some cases, when same-sex families are regarded, ignoring their existence by society and institutions reduces the possibility for data research, whilst as far as multi-ethnic families are concerned we have a limited number of studies available. For that reason, we decided to conduct a qualitative research which will optimistically precede a next larger quantitative research. Our study is a research on the perception of new family models in North Macedonia, more precisely on cohabiting families, homosexual families and multiethnic families, and includes the comparison between two different generations' opinions. Our hypothesis was that older generations are less likely to accept new family forms than the youth, while the second assumption is that same-sex families are least accepted by both age groups as a result of the high level of homophobia in our country and the region in general (Weiss, Bosia, 2013).

Our research was conducted from October to December 2019 in the major cities of North Macedonia: Skopje, Kumanovo, Debar, Bitola, Shtip, Ohrid, Kocani, Prilep, Veles, with the largest number of respondents originating from the capitol Skopje (43 out of a total of 62 respondents). The respondents were divided into two age groups in order to present a comparative analysis of their views and perceptions: (1) first age group from 45 to 60 years old (28 respondents) and (2) second age group from 20 to 35 years old (34 respondents). The selection of respondents from urban areas is due to the fact that the family models we analysed are less accepted in rural areas of the country, where social and family pressure, as well as stigma, are more pronounced (Авировиќ, 2017). The study was led using a structured questionnaire conducted live or online/by phone, depending on the possibilities for meeting with the respondents. The questionnaire consists of nine topics with sub-questions with the possibility of open answers, and in this paper we will present the results of the section dedicated to new family models, that is respondents' perception regarding cohabiting families, multi-ethnic and homosexual families.

The respondents of the first age group (45-60 years) expressed their positive opinion only for cohabiting families. Namely, the majority of respondents (14) accept this family model or link it with married families, since they 
usually consider that the only difference between the two models is the validation of the relationship ("it is just a signature") through a civil or religious marriage ceremony. Although positively accepted, the opinion of the majority is that cohabiting families should eventually transform into marriage. Many respondents (10) had a negative attitude towards cohabiting families, usually without elaborating their opinion, but in general the answers referred to the "dishonest intentions" of both or one partner in the relationship. The rest of the respondents (4) expressed a neutral attitude towards cohabitation. The data of this study are similar to those of our previous quantitative research from 2016 on "Perception of Youth (18-22 years) from Macedonia about Divorce and Cohabitation" in which more than half of the respondents stated that their parents (whose age corresponds to the respondents from the first age group) would not agree to live in a cohabiting family (Avirovic, Radulovic, 2016).

When asked to express and elaborate their opinion on multi-ethnic families or mixed marriages, the majority of our respondents (19) had a negative answer. However, it must be noted that most often they did not reject these families but qualified them as "complex", "subject to social disapproval", or with the possibility of "affecting negatively the children". They often pointed out that when it comes to multi-ethnic/multiracial families, it would be better for the partners to be of the same faith because, as one of our respondents (50 years old female respondent from Skopje) stated: "[...] one partner will always submit to the faith of the other". The other respondents had a positive (5) or neutral opinion (4) on mixed marriages. Since North Macedonia is a multi-ethnic and multi-confessional state, we expected more positive answers regarding this family model. However, although religious tolerance and interaction between different ethnic groups have increased in recent years (Ristevska, Daskalovski, 2011), it is clear that when it comes to interpersonal relations, partnership and the private sphere, our citizens have certain hesitations.

The results of the first group of respondents' opinions on homosexual families are similar to those of mixed marriages with 20 negative, 4 positive and 4 neutral answers. The majority of respondents do not support this family model, repeatedly due to religious reasons or because "reproduction between persons of the same sex is not natural" (female respondent from Debar, 45 years old). Many respondents underlined that homosexual couples were not a "natural phenomenon" and they should not have the opportunity to raise children. Furthermore, some respondents, besides not accepting these relationships, disapprove them.

When it comes to the opinion of the younger group of respondents (2035), their answers did not differ drastically compared to those of the previous age group. Namely, the majority of respondents (16) support cohabiting families and accept them as "normal", whilst 10 respondents believe that if two partners have decided to live together, they should get married, since cohabiting families are "unstable unions". Eight respondents expressed a neutral attitude towards cohabitation. These data were not surprising and were similar to a previous quantitative survey on cohabitation from 2017 conducted on married 
couples and cohabiting couples from North Macedonia. Namely, the results of that research indicated that half of the respondents equated marital union and cohabitation (Авировиќ, 2017).

Youth's opinion on multi-ethnic families are similar to those of the previous age group. The majority (14) does not accept mixed marriages, mostly because of the possibility of social exclusion, particularly for partners of different religious belief. However, a large proportion of respondents (11) accept multiethnic families and believe that ethnic and religious differences should not be an obstacle to the happiness of partners. Eight respondents expressed a neutral attitude towards these families, that is neither accept nor disapprove mixed marriages, while two respondents did not express their opinion. Although more tolerant of the older age group, when it comes to marriage and family, younger people also prefer a partners from the same religious group, generally in order to avoid conflicts with families or social stigma.

Regarding homosexual families, the majority of respondents (17) do not accept them, mostly due to the impracticability of reproduction, however, even in the case of adoption, they expressed a negative attitude, believing that it would be an "unhealthy environment for the child". Even those respondents (8) who accept homosexual relationships are against adoption rights to same-sex couples and they would not support a homosexual relationship by their children. The other respondents (9) expressed a neutral attitude towards homosexual families, that is neither accepting nor disapprove them.

According to the results from our qualitative research, our first hypothesis that older respondents are less tolerant than younger ones was not confirmed, as the differences in responses were not significant, especially when it comes to multi-ethnic families and same-sex couples. The only difference between the two age groups is their perception on cohabitation, which is more accepted by the youth. As for homosexual couples, the hypothesis that they are the least accepted family model by all respondents was confirmed since more than half of the respondents expressed a negative or neutral opinion towards them. The positive results on the perception of cohabiting families were also predicted and coincided with several previous above-mentioned studies, which indicates that cohabitation is the most socially accepted new family model in Macedonian urban areas, as it corresponds to the dynamic life of the youth, and at the same time can easily transform to marriage upon agreement of the partners.

\section{Conclusion}

The Industrial Revolution in Europe brought a series of social changes that undoubtedly affected family, its structure, functions, and relations between family members. Industrialization and urbanization have defined the nuclear family, which is still the dominant family model in contemporary European society. After World War II, as a result of the emancipation of women, the diffusion of hippie ideals and feminist ideas, as well as the secularization of 
societies and increasing individualization, new family models with different structures emerged: reconstructed families, cohabiting families, single-parent families, multi-ethnic families, same-sex families etc.

The decline of social influence and moral constraints that have been a feature of the past societies has led to a greater acceptance of different family models that were unacceptable in traditional patriarchal societies. In North Macedonia, as well as in the Mediterranean countries in Europe, new family forms are accepted more slowly than in Northern Europe, where cohabitation in particular has been accepted as an alternative to marriage since the 1990s (Nazio, $2008,15)$. The reasons for diverse family dynamics on the line north-south are the dissimilarities in family traditions, historical past, as well as different sociocultural context.

The results of our qualitative research on the perception of cohabiting families, multi-ethnic families and same-sex couples of different age groups from urban areas in North Macedonia suggests that although the number of these family models has increased in recent years, respondents' views are negative, especially towards mixed marriages and homosexual couples. In the case of multi-ethnic families, the different religious beliefs of the partners seem to be the biggest challenge along with the social pressure and the influence of the community. The less accepted of the two groups of respondents were same-sex families, a result that reflects the pronounced homophobia in Macedonian society, both among older and younger generations. Although the number of these couples is also increasing, they remain invisible in the public space, precisely because of the pronounced discrimination. The only family form that is typically accepted is cohabitation, as an alternative to marriage or as an overture to the marital union, in the form of a "premarital union". Although some scholars argue that cohabiting families are characterized by lower responsibilities between partners, that is a lower degree of attachment, a lower birth rate and a higher risk of separation (Nazio, 2008), they are moderately accepted in our society, especially by younger generations.

In order to obtain more detailed information about the perception of new family models in North Macedonia, we believe that further in-depth research with a statistically relevant sample is needed. Finally, this topic is at the same time very delicate and complex and deserves special attention and space. Further research is needed on all family models, as well as educating young people about the importance of family, marriage, partnerships, parenting, family values and gender roles within family, in order to increase awareness of the importance of family and reduce prejudices about different family models. 


\section{References:}

АвИРОвИќ, И. (2017). Дали предбрачните заедници го подобруваат бракот? Поглед кон семејната динамика во Македонија. Fourth International Scientific Conference: Social Change in the Global World - Proceedings. Штип: Унивезитет „Гоце Делчев“. 1099 -1113.

Avirovic, I., RADUlovic, M. (2016). Is De Facto Partnership a Threat to Marriage? A Case Study from Macedonia. European Journal for Social Sciences Education and Reseatcj (EJSER), European Center for Science Education and Research, January-April 2016 (Volume 6, Nr. 2).

ДРЖАВЕН ЗАВОД ЗА СТАТИСТИКА НА Р МАКЕДОНИЈА. (2004). Попис на населението, домаќинствата и становите 2002, Книга ХIII: Вкупно население, домаќинства и станови, според територијалната организација на Репубдика Македонија. Скопје: Завод за статистика на Р Македонија.

ДРЖАВЕН ЗАВОД ЗА СТАТИСТИКА НА РЕПУБЛИКА СЕВЕРНА МАКЕДОНИЈА. (2019). Соопштение: Наталитетот во Република Северна Македонија, 2018, по опитини. Скопје: Државен Завод за статистика на Република Северна Македонија. Преземено од:

http://www.stat.gov.mk/PrikaziSoopstenie.aspx?rbrtxt=8 (2.15.2020).

ЗАКОН ЗА СЕМЕЈСТВО, пречистен текст. (2014). Прв дел, ОПшти одредби, член 13. Преземено од:

http://www.mtsp.gov.mk/wbstorage/files/zakon_semejstvo_osnoven.pdf (10.5.2020).

KARRAKer, M.W. (2008). Global Families. New York: Pearson Education, Inc.

LASLETT, P., WALL, R. (1972). Household and family in past time. Cambridge: Cambridge University Press.

Мицковиќ, Д. (2008). Семејството во Европа XVI - XXI век, Скопје: Културна установа Блесок.

Mitchell, A., Fries, M. (2016). The Effect of Knowledge on Attitudes toward Homosexual Behavior. Race, Gender \& Class , Vol. 23, No. 1-2, Race, Gender \& Class 2015 Conference (2016), pp. 183-202. Jean Ait Belkhir, Race, Gender \& Class Journal. Retrieved from: https://www.jstor.org/stable/10.2307/26529198 (14.5.2020).

NAZIO, T. (2008). Cohabitation, Family and Society. New York: Routledge.

OINONEN, E. (2008). Families in Converging Europe, a Comparison of Forms, Structures and Ideals. Palgrave Macmillan.

ПОПОСКА, Ж., СТОјАНОвСКИ, С. (2016). Истражувачки извештај - Влијание на стереотипите и етничката дистанца за појава на дискриминација, говор на омраза и криминал од омраза, Скопје: Мисија на ОБСЕ во Скопје. Достапно на https://www.osce.org/mk/skopje/295636?download=true (10.5.2020). 
QuiLICI, M. (2010). Storia della paternità. Dal pater familias al mammo, Roma: Fazi editore.

RISTEVSKA, M. DASKALOVSKI, Z. (eds). (2011). One Decade after the Ohrid Framework Agreement: Lessons (to be) Learned from the Macedonian Experience. Skopje: Friedrich Ebert Stiftung and Center for Research and Policy Making Skopje. Retrieved from:

http://www.crpm.org.mk/wp-content/uploads/2017/12/OneDecade.pdf (10.2.2020).

Wall, R., Hareven, T. K., EhMer, J., Cerman, M. (eds). (2001). Family History Revisited, Comparative Perspectives, Newark: University of Delaware Press.

WeISS, M.L., BosiA, M.J. (eds.). (2013). Global Homophobia, States, Movements, and the Politics of Oppression. University of Illinois Press. Retrieved from: http://www.jstor.com/stable/10.5406/j.ctt3fh5hk.8 (14.5.2020). 